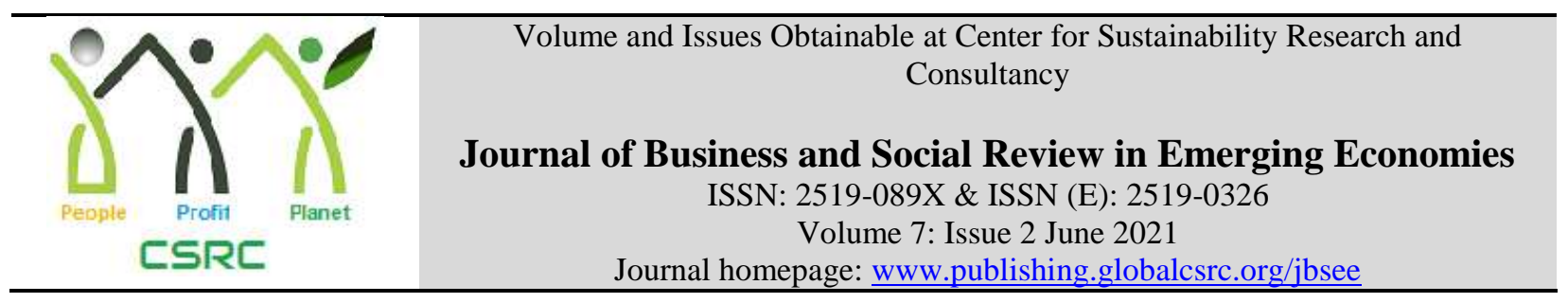

\title{
Impact of Psycho-Social Dimensions in Adoption and Use of Credit Cards. An Empirical Study from Pakistan
}

\author{
*Sohail Saeed, Department of Accounting and Finance, The Islamia University of Bahawalpur \\ Areeba Khan, Institute of Business Management and Administrative Sciences, The Islamia \\ University of Bahawalpur
}

Hina Shamshad, The Islamia University of Bahawalpur

*Corresponding author's email: sohail.saeed@iub.edu.pk.com

\begin{tabular}{l}
\hline ARTICLE DETAILS \\
\hline History \\
Revised format: Mar 2021 \\
Available Online: Apr 2021
\end{tabular}

\section{Keywords}

Psycho-Social dimensions, adoption, credit card,

Pakistan

JEL Classification

M11, M12

\begin{abstract}
Purpose: The main purpose of this study is to explore those psycho-social factors which are affecting the usage of credit cards in the present day. Furthermore, it is also aimed to investigate the impact of those factors like parental involvement, religiosity, impulsivity, compulsivity, locus of control, social status, customer attitude and financial distress on credit card usage in the context of Pakistan. Design/Methodology/Approach: For the purpose, the questionnaire has developed and distributed among users of credit cards in Bahawalpur region of Pakistan. This research is quantitative in nature and a probability sampling technique has been used to collect data. Moreover, regression analysis is used

Findings: The results reveal that parental involvement, compulsivity, and financial distress have a significant impact on credit card usage. However, the study failed to find out any impact of impulsivity, locus of control and religiosity on credit card usage. Similarly, the customer attitude and social status also did not have any impact on usage of credit cards. Implications/Originality/Value: The results of this study extend help to the banks, financial institutions and, particularly, futures researches in the field of digital currency. It is the time to start developing new digital banking tools.
\end{abstract}

(C) 2021 The authors, under a Creative Commons AttributionNonCommercial 4.0

Recommended citation: Saeed, S., Khan, A. \& Shamshad, H. (2021). Impact of Psycho-Social Dimensions in Adoption and Use of Credit Cards. An Empirical Study from Pakistan. Journal of Business and Social Review in Emerging Economies, 7 (2), 301-310

\section{Introduction}

In the whole world, as we know, banks are the most important and are playing a major role in a country's development and economic growth. Banks are beneficial in every field like in trade, agricultural development purposes, industrial development purposes, capital generation, credit generation, production of money, and transmit of money, and they also play a significant role in 
the economic welfare of the countryside. Introducing of plastic money is one of the most innovative works of banks. One of the most modern and convenient ways of transferring money is plastic money. The change of this digital system of payment is very valuable for all. This digital method is very fast, easy, and cheap for the different transactions, and in this method, there is less crime risk of cards reduced by plastic money. Credit cards, debit cards, (ATM) cards are part of plastic money. Varieties of different facilities are offering credit cards. It is one of the sources of the fastest transactions for its customers (Brito \& Hartley, 1995). It has been stated by (Khare et al., 2012) that those persons who have credit cards feel more comfort if even they do not have too much money. Credits cards are also a source of an idealized lifestyle. Married persons and those who have more income level hold credit card usually (Bulut and Koprulu, 2012). It is also possible that very intelligent people do use of the card.

Johan and Putit, (2015) argued that credit card is known as plastic money in the present modern world it might be used as a tool of payments. It gives the facility to its user it can buy any services and goods without meeting with the seller. Many countries are famous in the credit market like Canada, the USA, and Australia. According to the previous study, European countries' credit cards using ranged has been increased as compared to 2002 it has reached more than 59 million observed in 2016 (Thomas et al., 2005). He has done a lot of work on credit cards, (ATM), with the respect to different prospective like consumer behavior, credit card market, and banking. They also stated results that financial institutions were also given enough training to its consumers before the services were delivered. As we know, day by day competition is increasing in the banking sectors. Banks have been providing a lot of facilities like providing many financial facilities; financial derivatives, foreign exchange trading services, and foreign exchange trading, etc. Banks are also adopting many technologies in their services. It is expected credit cards have become the most popular among their services. In the recent era, there is an increase in credit card usage according to its volume and usage. But people are failed in their credit card payments. Therefore, this study aims to fill this particular gap that psycho-social factors towards credit card usage with data collected from its customers. The main objectives are to analyze the impact of independent variables like Parental involvement, compulsivity, impulsivity, locus of control, religiosity, financial distress on credit card usage which is dependent variable.

\section{Literature Review}

Kinsey, (1981) established research on credit card factors and stated that far above the ground in income is the most contributing factor in the growing number of a credit cards. This research is concentrating on the behavior of credit card users and this study was conducted by America and Canada. Kaynak and Uzmen, (1995) stated that credit cards are more secure than cash. That is one of the main reasons people preferred credit cards. Increased credit cards limit, fair charges and lowinterest rates are the main factors for the more adoption of credit cards. Chan, (1997) studied in Hong Kong and stated that low annual fee and low-interest repayment phase were the main factors in the selection of credit cards. Many researchers have paid their concentration on the user's choice of other payment methods compared to using debit cards. King and King, (2005) stated the major reasons why users prefer more debit cards than credit cards, and he also stated major reasons which fall in fear is debt in using a credit card, and the second reason is users of credit cards have not good history. Zinman, (2009) he also did research on plastic money and also has explained some more factors like time, rewards, motives, bankruptcy concerns, security concerns, and cost concerns. Butt et al, (2010) gathered data for the sake of selection criteria of credit card use data gathered from 800 card users he observed that factors security sense, convenience, these all have included as risk factors. These are very important factors in Pakistan from the card's selection points of view and another risk involves annual fees, interest rates, lack of awareness in people, security issues involve technical issues, and fear of loss of pin codes and issues like bankruptcy (Butt et al., 2010; Khalid et al., 2013). 
Impulsive buying has been stated as an unconscious, less deliberate irregular decision process (Solomon, 2007). It is stated that impulsivity is a process of buying in which individuals favor sudden actions and not bothering long-tern consequences. Other researchers stated that it is unplanned and unintended process in which individuals just focus on immediate satisfaction without the forethought of financial issues (Thomas et al, 2011-2012). According to the previous researches, impulsive behavior is defined as its unintentional and sudden urge to behave in a hedonically manner and on negative results acts without careful planning (Puri, 1996). For example, when a person purchased an extra expensive dress which is not in his or her budget, this is called impulsive behavior. Findings stated impulsive and compulsive these both traits have the same characteristics these both traits influence credit card usage and debt both. It is stated by (Solomon, 2007), that impulsivity is a short-term trait but compulsivity is an ongoing trait they both effects debt and credit card usage separately. And that both personality traits compulsivity and impulsivity are significantly affected the number of credit card owns by an individual. In credit card balances impulsivity is a significant independent variable. Compulsive purchasing stated as in which the individual cannot control his or her self from buying and individuals indulge in irregular and uncontrolled decision-making processes (Lo and Harvey, 2011). According to (Park and Burns, 2005) stated compulsive buying has a negative impact on consumer welfare and because of debt. In many studies, it is stated that due to compulsive buying behavior compulsive buyers possess many credit cards and they show less restraint while using these cards (O' Guinn and Faber, 1989; Roberts and Jones, 2001; Wang and Xiao, 2009). Previous studies also stated that college students possess more credit cards due to compulsive behavior them.

Compulsivity is the strong independent variable and it has a significant impact on an individual's own credit cards. Solomon, (2007) stated Compulsivity is long-term traits and impulsivity is for a specific period. Compulsivity is not a significantly predictor of balances of a credit card. In teenagers' individuals, compulsivity exists more that is adopted in by their factors of environment like family, parents, and friends. Parental involvement is positive phenomenon, parental involvement trains students for judicial credit card usage during attending college (Joo et al, 2003; Limbu et al, 2012). In social learning theory, it is stated that individuals learn from others' behavior and also learn by observing others. Parents are also answerable to persuade their children's credit card usage and behavior (Pinto et al, 2000). Joo et al., (2003) claimed that those individuals whose parents use more credit cards are more influenced by them. Hogan, 2003) noticed that most adults continue their lifestyle they enjoy while they living on their parent's income. Parents play important role in their children brought up about money beliefs and attitudes.

As a source of outcomes in terms of rewards punishments stated as the locus of control. It is stated that people have more internal control as compare to external (Wang et al, 2009). Pinto et al, (2004) stated that consumers with a locus of control have believed and control over their behavior losses and rewards. Similarly, Cost is the major reason which persons face in acceptance of the credit cards. Use of credit card also changes with interest rates stated by (Gan et al., 2008). Another result stated that anxiety is directly proportional to debt but anxiety is not associated with the numbers of credit cards a person owns. Gross and Souleless, (2002) he stated when credit increase that automatically causes a significant rise in debt. That mostly affects the young individuals and those how to have less income, Religious and cultural factors also affect the usage of credit cards. Over interest rates, many religious controversies influence the behavior of consumers of credit cards especially in Pakistan. According to the main principle of Islam, usury (Riba) is prohibited. According to the previous results, there is no relation exists between religiosity and credit card. Religiosity is just taken as spiritual wellbeing in daily activities. In financial matters, religiosity is not a significant factor. Many Muslims are not considered religiosity when they come to businesses (Souiden and Rani, 2015).

Users judge themselves and other people according to their possession they have, social status is a 
premium that facilitates the individual lifestyle (Limbu et al. 2012; Roberts and Jones 2001; Wang and Xiao, 2009). Stated by Limbu et al, (2012) that materialism and social status had significantly affected the credit card debt but not a significant impact on the number of credit card use. Credit card is used as a status symbol in India. In urban areas, where an increasing financial and economic conditions with growing prosperity, banks feel that the middle class is desirable to adopt this business line. According to (Mottola, 2012) when people use credit cards, they feel happy because they can take more debt to fulfill their family needs and wants. Devlin et al. (2007) established that credit card users are of two types; first one who used it for convenience and the second one who paid installment later on. Moreover, they further divided the types of users into groups. People who belong to low socio-economics status use credit cards for payments purposes and people who belong to high socio-economics status use the credit card for their convenience (Gan et al., 2008). Pulina, (2011) and Johan and Putit, (2015) observed that there was a fine relationship between credit card usage and consumer attitude. The reason of good relationship is because credit card helped its consumer to check and balance their spending. Another benefit was people who used a credit card never lost their money.

\section{Research Methodology}

There is a scattered population; a practicable method of sampling is used. The population of this study including credit card users of Bahawalpur, reliability tests are done to measure the reliability of questionnaires. Usually, two types of collecting sampling techniques are probability sampling and non-probability sampling. Daniel, (2011) stated probability sampling is a technique in which the selected population is known and in non-probability technique, the selected population is unknown and unselected. In this study, random sampling technique is used. In social sciences, it is the rule of thumb that there should be at least each response collect each item in the questionnaire. The researcher decides to collect data from 114 credit card consumers for reliable and consistent results. The questionnaire was developed for data collection. The questionnaire developed for the credit card consumers of Bahawalpur, Pakistan.

\section{Descriptive Statistics}

In this study minimum, maximum, mean, standard deviation, skewness, and kurtosis are discussed in descriptive analysis. The acceptable range of skewness is $-1+1$ and the kurtosis range is between $-3+3$. It is shown in Table 1 .

Table 1

\begin{tabular}{|l|l|l|l|l|l|l|l|}
\hline Variables & $\mathrm{N}$ & Minimum & Maximum & Mean & Std. deviation & Skewness & Kurtosis \\
\hline CBB & 114 & 1.00 & 5.00 & 2.9754 & 1.035 & 0.056 & -1.158 \\
\hline IBS & 114 & 1.00 & 5.00 & 2.8567 & 0.9455 & 0.166 & -1.105 \\
\hline FD & 114 & 1.00 & 5.00 & 3.0278 & 1.0187 & 0.021 & -1.077 \\
\hline PI & 114 & 1.00 & 5.00 & 2.9789 & 1.0287 & 0.173 & -0.976 \\
\hline RB & 114 & 1.00 & 5.00 & 2.1864 & 0.9101 & 1.042 & 0.914 \\
\hline LC & 114 & 1.00 & 5.00 & 2.8947 & 1.1307 & 0.478 & -0.926 \\
\hline CCU & 114 & 1.00 & 5.00 & 2.9756 & 0.9262 & 0.259 & -0.674 \\
\hline CA & 114 & 1.00 & 5.00 & 2.3677 & .77056 & 1.183 & 1.888 \\
\hline SSQ & 114 & 1.00 & 5.00 & 2.5112 & .8873 & 0.768 & 0.141 \\
\hline
\end{tabular}

The table shows that all the values are in the accepted range of skewness and kurtosis which confirms that there is no issue of normality of data. The most common measure of inter consistency is Cronbach's Alpha is called reliability. It is mainly used to find internal consistency among items. The acceptance criteria are that alpha value must be higher than 0.6 (Taber, 2018). There are different criteria of the acceptance of Alpha. The value of 0.9 considered excellent, 0.8 considered well, 0.7 considered Acceptable, 0.6 considered questionable and 0.5 considered poor. The data of reliability is shown in table 2 . The results show that there is no issue of reliability. 
Table 2

\begin{tabular}{lll}
\hline Variables & Cronbach's Alpha & Number of items \\
\hline Compulsivity & .860 & 5 \\
Credit card usage & .954 & 27 \\
Social status & .896 & 11 \\
Parental involvement & .902 & 10 \\
Financial distress & .925 & 12 \\
Impulsivity & .872 & 9 \\
Consumer attitude & .881 & 12 \\
Religiosity & .797 & 4 \\
Locus of control & .866 & 4 \\
\hline
\end{tabular}

\section{Correlation}

Correlation is a statistical measurement which indicates the relation between two variables. Its range is +1 to -1 . If the value comes greater than the positive and negative one its means there is an error. In the interpretation, these are indicators of correlation. -1 indicates a perfect negative linear relationship between variables and vice versa. The relationship among different variables of study is shown in table 3 .

Table 3

\begin{tabular}{|l|l|l|l|l|l|l|l|l|l|}
\hline & CBB & CCU & PI & FD & IBB & RB & LC & CA & SSQ \\
\hline CBB & 1 & & & & & & & & \\
\hline CCU & $.568^{* *}$ & 1 & & & & & & & \\
\hline PI & $.299^{* *}$ & $.497^{* *}$ & 1 & & & & & & \\
\hline FD & $.547^{* *}$ & $.609^{* *}$ & $.488^{* *}$ & 1 & & & & & \\
\hline IBB & $.481^{* *}$ & $.515^{* *}$ & $.456^{* *}$ & $.635^{* *}$ & 1 & & & & \\
\hline RB & .152 & $.376^{* *}$ & $.268^{* *}$ & $.263^{* *}$ & $.388^{* *}$ & 1 & & & \\
\hline LC & $.470^{* *}$ & $.517^{* *}$ & $.434^{* *}$ & $.600^{* *}$ & $.575^{* *}$ & $.519^{* *}$ & 1 & & \\
\hline CA & $.223^{*}$ & $.383^{* *}$ & $.258^{* *}$ & $.256^{* *}$ & $.467^{* *}$ & $.562^{* *}$ & $.420^{* *}$ & 1 & \\
\hline SSQ & $.437^{* *}$ & $.473^{* *}$ & $.422^{* *}$ & $.504^{* *}$ & $.643^{* *}$ & $.414^{* *}$ & $.532^{* *}$ & $.581^{* *}$ & 1 \\
\hline
\end{tabular}

$* *$ significant level is $<0.01 *$ significant level is $<0.05$

$\mathrm{CCU}$ correlation value with $\mathrm{CBB}$ is 0.568 which shows a very strong positive relation at 0.01 level of significance. CCU correlational value with PI is 0.497 which indicates a significant positive relationship among them. CCU correlational value with FD is 0.609 which indicates strong positive relationship. CCU shows a strong relationship with IBB (0.515). CCU correlational value with RB is 0.37 which indicates a positive relationship among them. CCU correlation value with LC is 0.517 which indicates a moderate positive relation among these variables. All variables are significantly correlated except religiosity and compulsive buying behavior because its significance level is 0.152 which is not acceptable. Moreover, there should not be the correlation among independent variables greater than 0.8 . Table 4 shows that there is no multicollinearity exists between independent variables. All variables correlation value is $<0.8$.

\section{Regression Analysis}

In order to test the impact of independent variables on credit card usage, regression model is run and the results are shown in table 5.

Table 5

\begin{tabular}{|l|l|l|l|l|}
\hline Model & $\mathbf{R}$ & R Square & Adjusted R Square & Std. Error of the Estimate \\
\hline 1 & $.735^{\mathrm{a}}$ & .540 & .505 & .65154 \\
\hline
\end{tabular}


a. Predictors: (Constant), LC, PI, CBB, RB, IBB, FD, CA, SSQ

In this table, model summary shows $\mathrm{R}$-value is 0.735 which indicates the strongly positive relationship between independent and dependent variables and $\mathrm{R}$ square value indicates how much overall impact of our model is on the dependent variable. $\mathrm{R}$ square value is 0.540 which indicates that the overall impact is $54 \%$ on the dependent variable. $\mathrm{R}^{2}$ adjusted is 0.505 which is not greatly less than $\mathrm{R}^{2}$ value which also indicates that the independent variables are not similar and they are independent of each other. The result of ANOVA is shown in table 6.

Table 6

\begin{tabular}{|l|l|l|l|l|l|l|}
\hline \multicolumn{2}{|l|}{ Model } & Sum of Squares & do & Mean Square & F & Sig. \\
\hline 1 & Regression & 52.359 & 8 & 6.545 & 15.418 & $.000^{\text {b }}$ \\
\cline { 2 - 7 } & Residual & 44.573 & 105 & .425 & & \\
\cline { 2 - 7 } & Total & 96.932 & 113 & & & \\
\hline
\end{tabular}

In this table, ANOVA reports how well the regression equation of regression fits data and gives information about model fit and shows whether it is significant or not. The significant value is 0.000 and the f value is 15.4 . It indicates that the regression model statistically significantly predicts the outcome variables. The significance and contribution of each independent variable on dependent variable is shown in the table 7.

Table 7

\begin{tabular}{|c|c|c|c|c|c|c|}
\hline \multirow{2}{*}{\multicolumn{2}{|c|}{ Model }} & \multicolumn{2}{|c|}{ Unstandardized Coefficients } & \multirow{2}{*}{\begin{tabular}{|c|}
$\begin{array}{l}\text { Standardized } \\
\text { Coefficients }\end{array}$ \\
Beta
\end{tabular}} & \multirow{2}{*}{ T statistic } & \multirow[t]{2}{*}{ Sig. } \\
\hline & & B & Std. Error & & & \\
\hline \multirow{9}{*}{1} & (Constant) & .216 & .268 & & .807 & .422 \\
\hline & CBB & .282 & .075 & 316 & 3.785 & .000 \\
\hline & SSQ & -.017 & .104 & -.017 & -.168 & .867 \\
\hline & PI & .187 & .071 & .208 & 2.622 & .010 \\
\hline & FA & .257 & .091 & .282 & 2.819 & .006 \\
\hline & IBS & -.012 & .100 & -.013 & -.123 & .902 \\
\hline & $\overline{\mathrm{CA}}$ & .148 & .110 & .123 & 1.341 & .183 \\
\hline & RB & .143 & .089 & .140 & 1.602 & .112 \\
\hline & $\mathrm{LC}$ & .001 & .081 & .001 & .007 & .995 \\
\hline
\end{tabular}

This table of coefficient has four columns of unstandardized coefficients, standardize coefficients, $\mathrm{t}$ value, and significant value. Table shows that value of (CBB), (PI) and (FA) are significant on different levels CBB at 0.000 highly significant, (PI) is at .010 and (FA) is at .006 . The $t$ values of CBB, PI and FA are 3.785, 2.622 and 2.819 respectively. These three variables have a significant impact on the dependent variable. How much change occurs in the dependent variable through the independent variable which is indicated through unstandardized Beta value. So, CBB will cause .282 means $28.2 \%$ impact on dependent variable, PI will cause .187 means $18.7 \%$ impact on 
dependent variable and FA cause .257 means $25.7 \%$ impact on dependent variable. Therefore, CBB, PI, and FA have positive impact on the credit card usage in Pakistan.

\section{Conclusion}

In this portion of the study, the results are compared with the previous study to reach on a conclusion. It is stated by (Solomon, 2007) that in credit card balances, impulsivity is a significant independent variable. Results are contradictory to the previous research because there is no significant impact of impulsivity found on credit card usage. Stated by many authors like (Roberts and Jones, 2001) that significant relationship exists between compulsive behavior and credit card usage. In this study, results are similar to the previous study. There is also a significant impact of compulsivity on credit card usage.

Joo et al, (2003) stated that those individuals whose parents use more credit cards are more influenced by them. In this study, there is also a significant impact of parental involvement on credit card using. These results are consistent with the previous studies. In previous results, social status has a significant relationship with credit card usage as stated by Limbu et al. (2012) that materialism and social status have significantly affected the credit card debt but not a significant impact on a number of credit card use. However, in this study, there is no significant impact of social status on credit card usage. Similarly, Plunkett \& Buehner, (2007) argued that locus of control was as the strongest independent variable as students credit card balances. In this study, there is no significant impact of locus of control on credit card usage. Another result stated that distress is directly proportional to debt but distress is not associated with the numbers of credit cards a person owns. Gross and Souleless, (2002), stated when credit increase that automatically causes a significant rise in debt. In this study, there is also a significant impact of financial distress and credit card usage. Hence, results are consistent with past results. In financial matters, religiosity is not a significant factor. Many Muslims are not considered religiosity when they come to businesses (Souiden and Rani, 2015). There is no significant relationship between a credit card and religiosity. In this study too, there is no significant impact of credit card use and religiosity. The results are consistent with the past studies. At the end, Pulina, (2011) and Putit \& Johan, (2015) observed that there is a fine relationship between credit card usage and consumer attitude but in this study, there is no significant impact on credit card usage by the consumer attitude. Therefore, this study concludes that there is a significant impact of parental involvement and compulsivity on credit card use. Religiosity, impulsivity, and religiosity have no significant impact on credit card use. This study is applicable to the banks. Though, this study is done on a very small scale but can be extended to larger scale. It is recommended that Banks's offerings of plastic money should be more attractive and innovative.

\section{References}

Brito, D. L., \& Hartley, P. R. (1995). Consumer rationality and credit cards. Journal of Political Economy, 103(2), 400-433.

Bulut, Y., \& Köprülü, O. (2010). Credit card market and socio-economic background of card holders: A case study from Turkey. Journal of Economic \& Management Perspectives, 4(4), 623.

Butt, B. Z., Rehman, K. U., Saif, M. I., \& Safwan, N. (2010). Customers credit card selection criteria in perspective of an emerging market. African Journal of Business Management, 4(14), 2934-2940.

Chan, R. Y. K. (1997). Demographic and attitudinal differences between active and inactive credit cardholders-the case of Hong Kong. International Journal of Bank Marketing.

Daniel, J. (2012). Sampling essentials: Practical guidelines for making sampling choices. SAGE Publications, Inc. https://www.doi.org/10.4135/9781452272047

Devlin, J. F., Worthington, S., \& Gerrard, P. (2007). An analysis of main and subsidiary credit card holding and spending. International Journal of Bank Marketing. 
Gan, L. L., Maysami, R. C., \& Koh, H. C. (2008). Singapore credit cardholders: ownership, usage patterns, and perceptions. Journal of Services Marketing.

Gross, D. B., \& Souleles, N. S. (2002). Do liquidity constraints and interest rates matter for consumer behavior? Evidence from credit card data. The Quarterly journal of economics, 117(1), 149-185.

Hogan, P. (2003). How to make personal finance connect with young adults. The AAII Journal, 25(3), 33-35.

Johan, Z. J., \& Putit, L. (2015). Consumers“ Acceptance of „Halal“ Credit Card Services: An Empirical Analysis. Journal of Emerging Economies and Islamic Research, 3(1), 51-59.

Joo, J., Park, Y. J., Oh, S., \& Kim, J. (2003). Quantum teleportation via a W state. New Journal of Physics, 5(1), 136.

Kaynak, E., Kucukemiroglu, O., \& Ozmen, A. (1995). Correlates of credit card acceptance and usage in an advanced developing Middle Eastern country. Journal of Services Marketing.

Khalid, J., Butt, H. S., Murtaza, M., \& Khizar, U. (2013). Perceived Barriers in the Adoption \& Usage of Credit Cards in Pakistan Banking Industry. International Review of Management and Business Research, 2(1), 104.

Khare, A., Khare, A., \& Singh, S. (2012). Factors affecting credit card use in India. Asia Pacific Journal of Marketing and Logistics.

King, A.S., King, J.T. (2005), The decision between debit and credit: fiance charges, flat, and fear. Financial Services Review, 14(1), 21-36

Kinsey, J. (1981). Determinants of credit card accounts: An application of Tobit analysis. Journal of consumer research, 8(2), 172-182.

Limbu, Y. B., Huhmann, B. A., \& Xu, B. (2012). Are college students at greater risk of credit card abuse? Age, gender, materialism and parental influence on consumer response to credit cards. Journal of Financial Services Marketing, 17(2), 148-162.

Lo, H. Y., \& Harvey, N. (2011). Shopping without pain: Compulsive buying and the effects of credit card availability in Europe and the Far East. Journal of Economic Psychology, 32(1), 79-92.

Mottola, G. R. (2013). In our best interest: Women, financial literacy, and credit card behavior. Numeracy, 6(2), 4.

O'Guinn, T. C., \& Faber, R. J. (1989). Compulsive buying: A phenomenological exploration. Journal of consumer research, 16(2), 147-157.

Park, H. J., \& Burns, L. D. (2005). Fashion orientation, credit card use, and compulsive buying. Journal of Consumer Marketing.

Pinto, M. B., Mansfield, P. M., \& Parente, D. H. (2004). Relationship of credit attitude and debt to self-esteem and locus of control in college-age consumers. Psychological reports, 94(3_suppl), 1405-1418.

Pinto, M. B., Parente, D. H., \& Palmer, T. S. (2000). Materialism and credit card use by college students. Psychological reports, 86(2), 643-652.

Plunkett, H. R., \& Buehner, M. J. (2007). The relation of general and specific locus of control to intertemporal monetary choice. Personality and Individual Differences, 42(7), 1233-1242.

Pulina, M. (2011). Consumer behaviour in the credit card market: a banking case study. International Journal of Consumer Studies, 35(1), 86-94.

Puri, R. (1996). Measuring and modifying consumer impulsiveness: A cost-benefit accessibility framework. Journal of consumer Psychology.

Roberts, J. A., \& Jones, E. (2001). Money attitudes, credit card use, and compulsive buying among American college students. Journal of consumer affairs, 35(2), 213-240.

Solomon, J. F. (2007). Corporate Governance and Accountability, (2nd ed.). New York:

Souiden, N., \& Rani, M. (2015). Consumer attitudes and purchase intentions toward Islamic banks: the influence of religiosity. International Journal of Bank Marketing.

Taber, K. S. (2018). The use of Cronbach's alpha when developing and reporting research 
instruments in science education. Research in Science Education, 48(6), 1273-1296.

Thomas, L. C., Oliver, R. W., \& Hand, D. J. (2005). A survey of the issues in consumer credit modelling research. Journal of the Operational Research Society, 56(9), 1006-1015.

Manoj Thomas, Kalpesh Kaushik Desai, Satheeshkumar Seenivasan, How Credit Card Payments Increase Unhealthy Food Purchases: Visceral Regulation of Vices, Journal of Consumer Research, Volume 38, Issue 1, 1 June 2011, Pages 126-139

Wang, J., \& Xiao, J. J. (2009). Buying behavior, social support and credit card indebtedness of college students. International Journal of Consumer Studies, 33(1), 2-10.

Zinman, J. (2009). Where is the missing credit card debt? Clues and implications. Review of income and wealth, 55(2), 249-265. 
